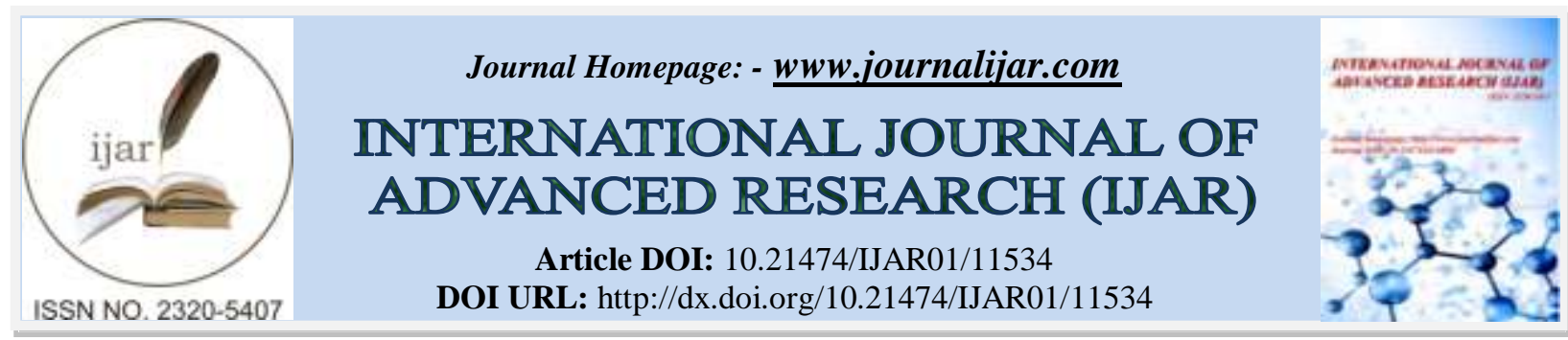

RESEARCH ARTICLE

\title{
ALVEOLAR RIDGE PRESERVATION
}

\section{Dr. Namrata M. Khetal ${ }^{1}$, Dr. Salman T. Ansari ${ }^{2}$, Dr. Rajvir Malik ${ }^{3}$, Dr. Sanjana J. Jirafe ${ }^{1}$ and Dr. Apeksha S. Gajghate $^{1}$}

1. PG Student, Department Of Periodontology, Swargiya Dadasaheb Kalmegh Smruti Dental College And Hospital, Nagpur, India.

2. Reader, Department Of Periodontology, Swargiya Dadasaheb Kalmegh Smruti Dental College And Hospital, Nagpur, India.

3. Professor And HOD, Department Of Periodontology, Swargiya Dadasaheb Kalmegh Smruti Dental College And Hospital, Nagpur, India.

\section{Manuscript Info}

Manuscript History

Received: 17 June 2020

Final Accepted: 19 July 2020

Published: August 2020

Key words:-

Ridge Preservation, Alveolar Process,

Residual Alveolar Ridge, Atrophy, Bone Grafts

\section{Abstract}

Alveolar process is an integral part of the periodontium lending osseous attachment to the teeth. However, being a tooth dependent anatomic structure, it develops in accordance with the developing tooth buds; moreover, it resorbs after tooth loss/extraction over a period of time. This physiologic phenomenon of resorption results in irregular and compromised ridge contour in various dimensions. Though the traditional prosthetic approaches to camouflage ridge defects are not obsolete; implant supported fixed prosthetic therapy is gaining a foothold in dental rehabilitation. Certain dimensional prerequisites for alveolar ridge are a must for implant success and survival. Present review outlines the interventions aimed at preservation of residual alveolar ridge and offers a comprehensive insight into regenerative materials that have been in use till date. Furthermore, it emphasizes upon the need for timely management of residual alveolar ridge for prompt rehabilitation of the patient.

Copy Right, IJAR, 2020,. All rights reserved.

\section{Introduction:-}

Alveolar process is a tooth dependent bony structure which develops in accordance with the developing tooth buds to provide osseous attachment to the developing periodontal ligament. ${ }^{1}$ The portion of the alveolar process that remains after teeth are lost is termed as Residual alveolar ridge. It comprises of the periosteum and residual alveolar bone underlying the mucosa and submucosa. ${ }^{2}$ The geometric form bestows a characteristic shape to the residual alveolar ridge. It may be rectangular, in which the buccolingual width is similar in its inferior and superior horizontal dimension. The ridge may be pyramidal; being the most common form, when the crestal horizontal dimension is narrower than the apical horizontal dimension. The ridge may be hour glass in shape having a constricture of the residual ridge when the crestal and apical horizontal dimension exceeds the width of buccolingual constricture. $^{3}$

Atrophy of the alveolar ridge which is attributed to short or long time span of edentulism follows a predictable pattern. Earlier studies have shown a wide variation amongst subjects with respect to post extraction dimensional alterations both clinically and radiographically; characterized by rapid reduction in both height and width. ${ }^{4,5}$ 
Although some degree of bone loss is evident at all the extraction sites, there is a greater loss of alveolar ridge width than height. ${ }^{6,7}$ This variability is attributed to genetic, anatomic, prosthetic, metabolic, functional or iatrogenic factors. ${ }^{8}$

Untimed extraction of teeth due to lack of post extraction treatment planning, leads to irregular resorption and uneven contours of the residual ridge. Centripetal resorption is exhibited by the upper jaw in which the labial cortical wall of the socket resorbs before the palatal wall; whereas, resorption of the lingual wall precedes that of the buccal in mandible, owing to centrifugal resorption. ${ }^{9}$ This discrepancy in pattern of resorption can lead to disruption in spatial relationship between the maxilla and mandible. ${ }^{10}$ To avoid the disruption, accurate diagnosis and planning the reconstruction of deficient alveolar ridge in respective areas for optimum long term results is imperative.

Prompt measures to halt the resorptive phenomenon play pivotal role in preserving a ridge which dimensionally equipped to support prosthesis. Moreover, the overlying soft tissue follows the underlying bony hard tissue contour; covering the alveolar ridge of the jaws and remaining firmly attached to the underlying bone. If the overlying mucosa and connective tissue are also lost at the time of injury and/or extraction, scarring of the soft tissue is inevitable. $^{11,12,13}$ Preservation of soft tissue is imperative for creating an aesthetic restoration which blends inconspicuously with the adjacent tissues.

\section{Etiology of tooth loss}

Loss of teeth and associated alveolar structures can be attributed to following ${ }^{14}$ :

1. Improper tooth extraction

2. Advanced periodontal disease

3. Abscess formation

4. Tumour

5. Trauma

6. Developmental and congenital diseases

7. Long standing peri-apical infections.

Extraction of teeth sets in a complex interplay of internal and external alterations responsible for bone formation within the socket and external loss of alveolar height and width. ${ }^{15}$ 


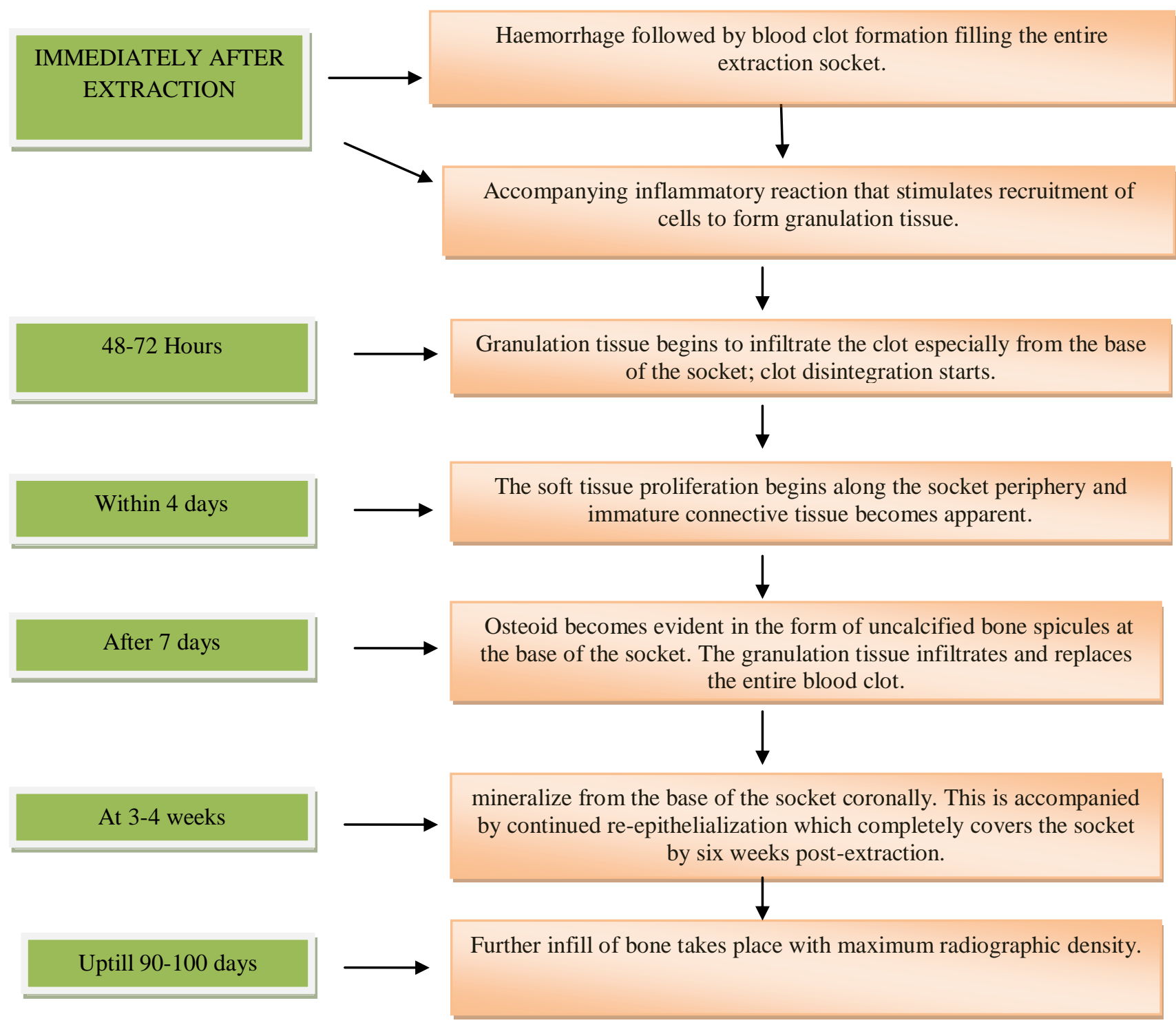

Figure 1:- Schematic Representation Of Internal Events In An Undisturbed Extraction Socket. ${ }^{16}$

External alterations accompany the internal events typically reducing both buccal and lingual walls in horizontal and vertical dimension. Araujo and Lindhe ${ }^{11}$ demonstrated marked osteoclastic activity resulting in the resorption of the buccal and lingual crestal walls in first eight weeks. Moreover, pronounced reduction of height at the buccal aspect has been evident. Disturbance in the events of healing results in impaired bone fill associated with discomfort and pain. Depending upon the stage of interruption, trivial hemmorrhage may progress further to dry socket, suppurative and/or necrotizing osteitis. ${ }^{17}$ Fibrous healing associated with lack of bone formation renders the ridge unsuitable for osteotomy for implant placement. ${ }^{17}$

The size of the socket and nature of bone loss influence the healing of extraction socket. Wider sockets take more time for infill and soft tissue approximation than the narrower one. Also a $100 \%$ bone infill in socket can rarely be expected since bone; more or less frequently, does not regenerate coronal its horizontal level or upto the level of adjacent teeth. Accordingly, extraction sockets associated with horizontal loss of crestal walls heal faster. ${ }^{15,18}$

Osteoporotic patients on bisphosphonate or PTH (Teriparatide) therapy may require extraction at any point of time. Bisphosphonates targets osteoclasts and suppresses remodelling of bone whereas, Teriparatide (PTH) therapy promotes remodelling. ${ }^{19,20}$ Kuroshima $\mathrm{S}$ et al ${ }^{21}$ studied the therapeutic effect of aforesaid drugs over socket healing 
and reported that both the therapies prevent vertical loss of bone. He confirmed that, Zoledronate (Bisphosphonte) therapy has deleterious effects whereas PTH therapy favours healing of oral tissues.

\section{Post Extraction Dimensional Alterations}

Following tooth loss/extraction, the supporting bone reorganizes itself in order to comply with the biologic principles of nature. This structural reorganization of residual alveolar ridge is manifested as resorption. Alveoli regress gradually when the teeth are lost, constituting the residual alveolar ridge. This physiologic process of remodelling of alveolar bone following tooth loss inevitably leads to certain dimensional alternations of residual alveolar ridge over a period of time. The most rapid changes in edentulous subjects are noted from six months to two years after extraction. ${ }^{22,23}$ Demonstrating the variability in resorption between the maxilla and the mandible, Atwood and $\mathrm{Coy}^{23}$ showed that mean alteration was four times higher in the lower jaw. Whereas, major changes after single tooth extraction were reported within 12 months of extraction with two-third of loss occurring within initial three months. ${ }^{15}$ Ashman ${ }^{24}$ showed that this deterioration further continues, leading to upto $40-60 \%$ loss of alveolar volume over a span of 3 years.

\section{Traditional Prosthetic Approaches For Deformed Alveolar Ridge}

The Era of Etruscans, marked $500 \mathrm{BC}$, reveals the use of customized soldered gold bands from animals and teeth from oxen bone to restore oral function in humans. ${ }^{25}$ Around $300 \mathrm{AD}$, Phoenicians utilized carved ivory teeth along with a gold wire for its stabilization, to create a fixed bridge. ${ }^{25}$ Before implant therapy became available, the physiology and healing pattern of edentulous ridge after extraction were often neglected and removable partial dentures (RPDs), fixed partial dentures (FPDs) or cast partial dentures (CPDs) sufficed the replacement of missing teeth; all of which rely on adjacent teeth and underlying alveolar mucosa for support with little consideration for the status of hard tissue.

In case of deformed alveolar ridge, various prosthetic mechanical methods were adopted to camouflage the ridge deficiency. For class I and less extensive class II and III defects, modified pontic design known as 'blended pontic' was employed by brining it in contact with the altered ridge. ${ }^{26}$ For extensive class III defects, use of Andrew's bridge system is reported. ${ }^{27,28}$ Conventional removable and fixed partial dentures are gradually being replaced by implant supported fixed prosthetic therapy.

\section{Rationale For Ridge Preservation}

A minimum amount of bone width and height is an essential prerequisite for successful implant placement. Unfavourable local conditions owing to defects in alveolar ridge, may provide insufficient bone volume or an unfavourable inter-arch relationship dismissing the placement of implants in prosthetically driven position. Preservation of width and height most predictably occurs at the time of tooth extraction, hence interventions aiming at maintainance of alveolar ridge to be able to support an implant supported prosthesis later, begin at the time of extraction. ${ }^{29,30,31}$ Ridge preservation is any procedure undertaken at the time of or following an extraction that is designed to minimize external resorption of the ridge and maximize bone formation within the socket. ${ }^{32}$

A standard body implant requires a minimum of 6-7 mm of bone dimension; this precludes most of the resorbed intraoral sites as unsuitable for implant placement. ${ }^{18}$ Hence, loss of bone dimension should be prevented with interventions like ridge preservation at the time of extraction or ridge augmentation as a primary procedure prior to implant placement.

\section{When To Preserve And When Not To Preserve?}

Anterior maxillary area is prone to rapid resorption which leads to compromised aesthetics over this crucial area. Januario et $\mathrm{al}^{33}$ assessed the thickness of facial bone in the anterior dentition using CBCT amongst periodontally healthy subjects and found that facial bone thickness of $\leq 1 \mathrm{~mm}$ is most commonly present in the anterior dentition. Moreover, nearly $50 \%$ of sites presented bone wall thickness of $\leq 0.5 \mathrm{~mm}$. Such thin facial bone undergoes remarkable deterioration post-extraction. Preservation of ridge is imperative at sites where the buccal plate is less than 1.5-2 mm thick and/or sites where there has been damage or loss of one or more of the socket walls. ${ }^{11,34}$ Ridge preservation is highly necessitated in clinical situations wherein tooth extraction precludes the involvement of anatomical structures in the vicinity such as neurovascular bundle in posterior mandible and maxillary sinus over posterior maxilla to avoid further complications. ${ }^{18}$ Meta analysis by Vittorini et al $^{35}$ also substantiates the aforesaid findings. Clinical situation of high smile line with excessive gingival display or a thin gingival biotype require preservation at the time of extraction since soft tissue therein in prone to recession. ${ }^{18}$ Moreover, preservation is ought 
to be considered in future pontic sites and/or denture bearing areas for conventional fixed and removable prosthodontic therapy. ${ }^{18}$

However, certain clinical situations dismiss undertaking ridge preservation at the time of extraction owing to hazardous squeal which might ensue. More or less frequently, inflammation is self-limiting however, ${ }^{36}$ in the presence of a substrate (e.g.tooth), the biofilm becomes difficult to eliminate since it provides a niche for resident flora. $^{37,38}$ Removal of the involved substrate favours internal events of socket healing hence, preservation and/or immediate implantation is to be avoided in the presence of acute infection. Recent consensus has been reached which states that minimal dimensional change occurs within six to eight weeks of an extraction; accordingly, preservation of the ridge can be deferred until then. ${ }^{39}$

\section{Material Utilized For Alveolar Ridge Preservation}

Interventions aiming at preservation of alveolar ridge usually employ the principles of guided bone regeneration. A plethora of bone grafts and barrier membranes have been in use solistically and/or in combination to maintain the ridge width, height and position of the alveolar ridge. Nevertheless, grafting should always be preceeded by atraumatic extraction, thorough debridement, careful inspection of socket and soft tissue management.

\section{Atraumatic Extraction Of The Involved Tooth}

Necessity of sound supporting apparatus for implant therapy dictates atraumatic extraction. Removal of the tooth from the dentoalveolar apparatus might involve surgical removal of surrounding bone. ${ }^{40}$ Careful extraction involves minimal trauma to the investing tissues in order to prevent postoperative complications and favour uneventful healing. 40

Aristotle (384-322 BC) ${ }^{40}$ first described the mechanics of extraction forceps; later, physics forceps, benex extractor, periotome, piezosurgery, sonic instruments for bone surgery, lasers and endoscopically assisted root splitting came in use. ${ }^{40}$ Fine luxators and periotomes to severe the coronal attachment of fibres whereas root sectioning for multirooted teeth are appropriate for avoiding trauma to investing tissues. ${ }^{18}$

\section{Debridement And Inspection Of The Extraction Socket}

Healing proceeds through a cascade of events; which if uninterrupted results in consolidation of the extraction socket. Literature reveals a paradox over healing of sockets since some authors state that anything which might interfere with the early and delayed stages of healing (eg: foreign body, bony spicules etc) should be removed whereas, some suggest that use of a round bur to perforate the socket favours bone infill. ${ }^{18,41}$ Nevertheless, chronically inflamed tissue and foreign material is to be removed.

Soft tissue management at the time of extraction profoundly influences the esthetic outcome. Lee et al ${ }^{42}$ reported a meta analysis which favours flapless approach to be more effective in preserving bone width, height and width of keratinized gingiva. Nevertheless, for a flapped approach, raising only buccal/facial flap while preserving the papilla shall be a suitable alternative. Although not contributing directly to regeneration; covering the socket with soft tissue is considered to stabilize the bone graft and involves either free (gingival or subepithelial connective tissue grafts) or pedicled (coronally advanced labial/buccal flap, rotational flaps) autografts. ${ }^{18,43,44,45}$

Hegedus in $1923^{46}$ reported the use of bone grafts for reconstructing intraosseous defects; which subsequently found application in ridge preservation. The material and surgical techniques facilitate ridge preservation and augmentation prior to or simultaneous to implant placement enabling us to predictably ensure the functional and aesthetic outcomes of the implants. ${ }^{29,47,48}$

Bone replacement grafts for ridge preservation are defined by the American Dental Association as osseous autograft, allograft or non-osseous graft placed in an extraction site at the time of extraction to preserve ridge integrity. ${ }^{49}$ Allegrini et $\mathrm{al}^{50}$ reported that ridge preservation decreased early alveolar ridge width loss after tooth extraction.

\begin{tabular}{|c|c|c|c|c|c|}
\hline \multicolumn{2}{|c|}{ AUTOGRAFT } & \multirow[t]{2}{*}{ ALLOGRAFT } & \multirow[t]{2}{*}{ XENOGRAFT } & \multirow[t]{2}{*}{ ALLOPLASTS } & \multirow{2}{*}{$\begin{array}{c}\text { Non bone graft } \\
\text { materials }\end{array}$} \\
\hline Intra-oral & $\begin{array}{c}\text { Extra- } \\
\text { oral }\end{array}$ & & & & \\
\hline Osseous coagulum & Tibia & Freeze dried bone & Calf bone & Porous & Cartilage \\
\hline
\end{tabular}




\begin{tabular}{|c|c|c|c|c|c|}
\hline & & allograft (FDBA) & hydroyapatite & Sclera \\
\hline Bone blend & $\begin{array}{c}\text { Iliac } \\
\text { crest } \\
\text { dried bone allograft } \\
\text { (DFDBA) }\end{array}$ & $\begin{array}{c}\text { Decalcified freeze } \\
\text { hydroxyapatite }\end{array}$ & Anorganic bone & Bioactive glass & $\begin{array}{c}\text { Calcium } \\
\text { phosphate }\end{array}$ \\
\hline Bone swaging & & & HTR polymers & $\begin{array}{c}\text { Tricalcium } \\
\text { phosphate }\end{array}$ \\
\hline $\begin{array}{c}\text { cancellous bone } \\
\text { marrow transplant }\end{array}$ & & & $\begin{array}{c}\text { Beta tricalcium } \\
\text { phosphate }\end{array}$ \\
\hline
\end{tabular}

Table 1:- Overview of bone grafts based upon classification by Carranaza FA, Newman MG (1999) ${ }^{51}$.

\section{Autogenous Bone Grafts}

Hyatt and Butler ${ }^{52}$ classified autografts as tissue taken from one operative site and grafted in another operative site within the same individual. They are biocompatible with osteogenic, osteoinductive as well as osteoconductive properties. ${ }^{53-56}$ Out of the three harvested forms, cortical, cortico-cancellous and cancellous; the latter are generally preferred owing to its rapid revascularization and tissue integration. ${ }^{55}$ Cortical autografts are capable of forming necrotic foci owing to a greater rate of apposition replacement and bone matrix resorption. ${ }^{55}$ It is possible to harvest autogenous bone in block and/or particulate form, from intra-oral as well as extra-oral sites; although the latter is less frequently preferred owing to disadvantages like additional surgical site, unpredictable bone quality, and prolonged recovery time. ${ }^{54,57}$

Rivault $\mathrm{AF}^{58}$ stated that small bone particles of 100 micrometers could provide an earlier and greater osteogenic activity. Osseous coagulum is a mixture of blood with autogenous intraoral bone obtained with high or low speed round bur. ${ }^{59}$ Overcoming its drawback of inability to aspirate and unknown quality and fluidity of the material; bone blend was introduced which is cortical or cancellous bone procured with a trephine or rongeurs, placed in an amalgam capsule and triturated to the consistency of a slushy osseous mass. ${ }^{59}$ The resultant particle size is in the range of $210 \times 105$ micrometers. ${ }^{60}$ Nevertheless, its use is of questionable value in ridge preservation, due to paucity of literature.

Autografts cumulatively have certain disadvantages and hence despite of being the 'gold standard', its application in ridge preservation is gradually diminishing. Iasella et $\mathrm{al}^{31}$ demonstrated the advantages of alternative bone graft materials for ridge preservation.
Allografts
The types of allografts used are: ${ }^{61}$
1. Frozen iliac cancellous bone and marrow
2. Mineralized freeze dried bone allograft (FDBAs)
3. Decalcified FDBAs (DFDBAs).

Hyatt and Butler ${ }^{52}$ classified allografts/homografts as tissue taken from one operative site in one individual and grafted in the operative site in another individual of the same species.

FDBAs and DFDBAs are most commonly employed grafts for ridge preservation, since its utilization has diminished the immunogenic concerns frequently associated with fresh frozen bone. ${ }^{56}$

Though they have found wide applications in regenerative therapy and ridge preservation; ${ }^{62}$ studies reveal conflicting data regarding its efficiency. Aspenberg $\mathrm{P}$ et al ${ }^{63}$ stated that DFDBA failed to accelerate bone formation. Histologic evidence from studies conducted by Becker et $\mathrm{al}^{64}$ and and Froum et $\mathrm{l}^{65}$ reported little new bone formed around the bone graft. Whereas, Yukna and Vastardis ${ }^{62}$ reported increased regeneration with FDBA compared to DFDBA in their histologic analysis and Dahlin et al ${ }^{66}$ stated similar treatment outcome for reconstruction of atrophic maxillae with the utilization of DFDBA in comparison with extraoral autograft.

\section{Xenografts}

Hyatt and Butler ${ }^{52}$ classified xenografts as tissue taken from one individual and grafted in the operative site of another individual of the different species. They are biocompatible, osteoconductive and rarely associated with 
formation of interposition areas of connective tissue. ${ }^{67}$ Xenografts are derived from porcine, bovine, equine and coralline; however, bovine is most frequently used. ${ }^{67,68}$ Bovine bone offers optimum retention of the graft; upto 20$40 \%$ after six months as well as upto two postoperative years probably attributed to long-term space maintainance due to its slow rate of substitution. ${ }^{68}$

Histological studies show optimum integration of bovine particles. ${ }^{69}$ Artzi et a ${ }^{70}$ demonstrated the histologic appearance of a mixture of bovine bone graft (Bio-Oss) and new bone formation. Moreover he reported $82.3 \%$ bone infill and safe insertion of fixtures using a common porous bovine bone graft (Bio-Oss) in fresh extraction sockets, covering the graft with soft tissue.

Nevins et $\mathrm{al}^{71}$ evaluated the use of Bio-Oss as bone filler, by assessing the fate of buccal bone in anterior maxilla and demonstrated a loss of less than $20 \%$ of the buccal plate in $(79 \%)$ of test sites whereas, $(71 \%)$ of test sites demonstrated a loss of more than $20 \%$ of the buccal plate. Hence, although resorption is inevitable, test sites benefited by grafting at the time of extraction.

\section{Alloplasts}

Alloplasts are synthetic, biocompatible, inorganic bone substitutes which favour regeneration through its osteoconductive properties acting as biologic filler. ${ }^{61,67}$ Alloplasts are available in ample amount, wherein particle size can be customized by the manufacturer; moreover, they are free from the risk of disease transmission and immunogenic concerns. ${ }^{67}$

The earliest alloplastic graft which is capable of favouring bone regeneration in a contained lesion was Plaster of Paris although it is yet to be fully documented for human use. ${ }^{61,72}$ With the advent of new alloplasts; polymers, calcium carbonate and ceramics came into use. ${ }^{61}$ Ceramics can be resorbable (e.g., tricalcium phosphate and resorbable hydroxyapatite (HA) and nonresorbable (dense HA, porous HA, and bioglass). ${ }^{61}$ Owing to slow resorption rate, hydroxyapatite is suitable for alveolar ridge preservation. ${ }^{67}$

Nemcovsky and Serfaty ${ }^{73}$ evaluated the use of hydroxyapatite in fresh extraction sockets and reported predictable ridge preservation. Moreover, Mangano et $\mathrm{al}^{74}$ reported histologic and histomorphometric long-term evaluation of dense hydroxyapatite in sockets after extraction. He confirmed an intimate binding between grafts particles and bone, which contributes to graft stability. Guarnieri et al ${ }^{75}$ reported prompt resorption and $100 \%$ bone infill and successful placement of implants in extraction socket grafted with calcium sulphate.

\section{Use Of Barrier Membranes For Ridge Preservation}

Barrier membranes either resorbable or non-resorbable; have been employed to prevent soft tissue in growth and promote bone infill in the extraction socket. ${ }^{18}$ Lekovic et al ${ }^{7}$ investigated the use of a non-resorbable expanded polytetrafluoroethylene (ePTFE) membrane. Although bone infill was favoured by ePTFE membrane, however, high rate of membrane exposure associated with its use, jeopardized the healing. When the aforesaid group of authors utilized a polyglycolidelactide membrane (Resolute, WL Gore \& Associates), the experimental sites showed no membrane exposure coupled with satisfactory socket infill and less loss of alveolar dimension. ${ }^{6}$ Resorbable membranes offer better protection for graft material. An animal-derived membrane, Bio-Gide seems promising, although its use for ridge preservation is yet to be well documented. ${ }^{18}$

Use of barrier membranes along with bone grafts can favour better infill owing to graft protection. Iasella et al ${ }^{76}$ evaluated the use of tetracycline hydrated freeze-dried bone allograft and a resorbable membrane (Bio-Mend) compared to healing by blood clot alone. Although all the sites received implants, loss of width was less in grafted sites. Cases wherein primary closure of graft would lead to mucogingival problems, Fowler et a ${ }^{77}$ suggested use of an acellular dermal graft and utilized it in conjuction with DFDBA and found acceptable dimensions of tissue for implant placement.

\section{Space Fillers}

Serino et $\mathrm{al}^{78}$ evaluated commercially available bioabsorbable sponge of polylactide-polyglycolide placed into extraction sockets. The sponge served as an efficient barrier to adjacent soft tissue and strikingly, less bone resportion was noted especially in the mid-buccal region as compared to untreated sockets. A collagen plug (Collaplug, Zimmer Dental) seems promising, however; space fillers cumulatively, may aid in clot stabilization and may act as a barrier. Its accurate role in ridge preservation is not yet clearly documented. ${ }^{18}$ 


\section{To Preserve Or To Reconstruct?}

Most of the dental conditions which may lead to tooth loss are preventable or can be halted at early stages. However, painful dentoalveolar traumatic injuries predominate and patient most frequently seek prompt removal with very little consideration for further treatment planning. Nevertheless, loss of teeth is associated with aesthetic, functional and even psychological concerns to the patient. However, due to previous lack of treatment planning post extraction, most of the cases present with ridge defects at the dental office due to long time span of edentulism. This further

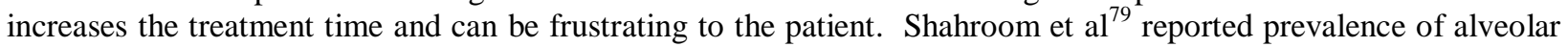
ridge defect amongst Indian population to be $91.6 \%$ due to trauma; Moreover he reported Siebert's class III defect to be most common followed by class I and class II ridge defects.

It is the need of the hour to prosthetically govern tooth extraction with prompt measures to preserve the dimensions of alveolar ridge as far as possible. Although alveolar ridge reconstruction as a simultaneous or staged procedure with provisionalization is promising when implant placement is anticipated; but it increases the overall treatment time.

\section{Conclusion And Future Perspective:-}

Placement of dental implants in prosthetically driven position, with optimum soft tissue aesthetics can be facilitated by preservation of overall dimensions of alveolar ridge. Although consensus regarding choice of technique, material for ridge preservation.is yet to be reached; a suitable technique will be one involving thorough treatment planning, atraumatic removal of tooth followed by debridement and grafting with a suitable bone graft with slow resorption rate in combination with a resorbable barrier membrane placed for graft protection. Moreover, like any surgical procedure, ridge preservation might be influenced by patient related factors, environmental factors which need to be taken into consideration. Marei et $\mathrm{al}^{80}$ demonstrated promising results of cultivated scaffolds from bone marrow mesenchymal stem cells placed in fresh extraction socket. This paves a way for incorporation of stem cell therapy for preservation of alveolar ridge.

\section{References:-}

1. Newman MG, Takei H, Klokkevold PR, Carranza FA. Carranza's Clinical Periodontology. Elsevier Health Sciences; 2011 Feb 14.

2. Hickey J, Zarb G, Bolender C. Biomechanics of the edentulous state. Boucher's prosthodontic treatment for edentulous patients. St. Louis: Mosby. 1975:3-9.

3. PP J. Suvarna PV. Dental CT third Eye in dental implants. Dental CT in Implantology, 1st edition. New Delhi, India: Jaypee Brothers Medical Publishers (P) Ltd. 2013.

4. Johnson K. A study of the dimensional changes occurring in the maxilla following tooth extraction. Aust Dent $\mathbf{J}$ $1969 ; 14: 241-244$.

5. Atwood DA. Post-extraction changes in adult mandible as illustrated by microradiograph of midsagittal section and serial cephalometric roentogenograms. J Prosthet Dent $1963 ; 13: 810-824$.

6. Lekovic V, Camargo PM, Klokkevold PR. Preservation of alveolar bone in extraction sockets using bioabsorbable membranes. J Periodontol 1998;69:1044-1049.

7. Lekovic V, Kenney EB, Weinlaender M. A bone regenerative approach to alveolar ridge maintenance following tooth extraction. Report of 10 cases. J Periodontol 1997;68:563-570.

8. Jahangiri L, Devlin H, Ting K, Nishimura I. Current perspectives in residual ridge remodeling and its clinical implications: a review. The Journal of Prosthetic Dentistry. 1998 Aug 1;80(2):224-37.

9. Elsalanty ME. Bone Development and Histiogenesis of the Jaws. Horizontal Alveolar Ridge Augmentation in Implant Dentistry: A Surgical Manual. 2015 Dec 14:19.

10. Abirami G. Residual ridge resorption in complete denture wearers. Journal of Pharmaceutical Sciences and Research. 2016 Jun 1;8(6):565.

11. Araújo MG, Lindhe J. Dimensional ridge alterations following tooth extraction. An experimental study in the dog. Journal of Clinical Periodontology. 2005 Feb;32(2):212-8.

12. Hickey JC, Zarb GA, Bolender CL. Prosthodontic treatment for edentulous patients. St. Louis: CV Mosby Company; 1975.

13. Ross R, Everett NB, Tyler R. Wound healing and collagen formation: VI. The origin of the wound fibroblast studied in parabiosis. The Journal of Cell Biology. 1970 Mar 1;44(3):645-54. 
14. Prato GP, Cairo F, Tinti C, Cortellini P, Muzzi L, Mancini EA. Prevention of alveolar ridge deformities and reconstruction of lost anatomy: a review of surgical approaches. International Journal of Periodontics \& Restorative Dentistry. 2004 Oct 1;24(5).

15. Schropp L,Wenzel A, Kostopoulos L. Bone healing and soft tissue contour changes following single, tooth extraction: a clinical and radiographic 12- month prospective study. Int J Perio Rest Dent. 2003;23:313- 323.

16. Amler MH, Johnson PL, Salman I. Histological and histochemical investigation of human alveolar socket healing in undisturbed extraction wounds. J Am Dent Assoc :1960;61:31-34.

17. Politis C, Schoenaers J, Jacobs R, Agbaje JO. Wound healing problems in the mouth. Frontiers in Physiology. 2016 Nov 2;7:507.

18. Darby I, Chen S, De Poi R. Ridge preservation: what is it and when should it be considered. Australian Dental Journal. 2008 Mar;53(1):11-21.

19. Chapurlat RD, Arlot M, Burt-Pichat B, et al. Microcrack frequency and bone remodelling in postmenopausal osteoporotic women on long-term bisphosphonates: A bone biopsy study. J Bone Miner Res. 2007; 22:15021509.

20. Dobnig H, Turner RT. Evidence that intermittent treatment with parathyroid hormone increases bone formation in adult rats by activation of bone lining cells. Endocrinology. 1995; 136:3632- 3638 .

21. Kuroshima S, Mecano RB, Tanoue R, Koi K, Yamashita J. Distinctive tooth-extraction socket healing: bisphosphonate versus parathyroid hormone therapy. Journal of Periodontology. 2014 Jan;85(1):24-33.

22. Tallgren A. The continuing reduction of the residual alveolar ridges in complete denture wearers: A mixedlongitudinal study covering 25 years. J Prosthet Dent1972;27:120-132.

23. Atwood DA, Coy WA. Clinical, cephalometric and densitometric study of reduction or residual ridges. J Prosthet Dent 1971;26:280-295.

24. Ashman A. Ridge preservation: important buzzwords in dentistry. Gen Dent. 2000;48:304-12.

25. Abraham CM. A brief historical perspective on dental implants, their surface coatings and treatments, Open Dent. J. 8 (2014) 50-55.

26. Abrams L. Augmentation of the deformed residual edentulous ridge for fixed prosthesis. Compend Contin Educ Gen Dent. 1980 May-Jun;1(3):205-213.

27. Ram SM. Management of Anterior Ridge Defect with Andrew's Bridge. Journal of Contemporary Dentistry. 2016 Sep;6(3):208-13.

28. Thaper T, Kumar S. Restoring Anterior Aesthetics With Andrews Bridge Using A Coffee Straw.

29. Levine RA, Horowitz RA. Bone reconstructive surgery for implant site preparation. Functional Esthetics \& Restorative Dentistry. 2007; Series 1 (No.2): 20-28; a supplement to Inside Dentistry, 2007, Vol. 3 (No.7).

30. Nevins M, Camelo M, De Paoli S. A study of the fate of the buccal wall of extraction sockets of teeth with prominent roots. Int J Periodontics Restorative Dent. 2006;26: 19-29.

31. Iasella JM, Greenwell H, Miller RL. Ridge preservation with freeze-dried bone allograft and a collagen membrane compared to extraction alone for implant site development: a clinical and histologic study in humans. J Periodontol. 2003;74:990-999

32. Chackartchi T, Stabholz A. Ridge preservation after tooth extraction: what do we know today. Refu'at ha-peh veha-shinayim (1993). 2013 Apr;30(2):65.

33. Januário AL, Duarte WR, Barriviera M, Mesti JC, Araújo MG, Lindhe J. Dimension of the facial bone wall in the anterior maxilla: a cone-beam computed tomography study. Clinical Oral Implants Research. 2011 Oct;22(10):1168-71.

34. Girard B, Baker G, Mock D. Foreign body granuloma following placement of hard tissue replacement material: a case report. J Periodontol 2000;71:517-520.

35. Vittorini Orgeas, G.; Clementini, M.; de Risi, V.; de Sanctis, M. Surgical techniques for alveolar socket preservation: A systematic review. Int. J. Oral Maxillofac. Implants 2013, 28, 1049-1061.

36. Kumar V, Abbas A, Fausto N 2005. Acute and chronic inflammation. In: Pathologic basis of disease. Kumar V, Abbas A, Fausto N, editors. St. Louis: Saunders-Elsevier, pp. 47-86.

37. Costerton JW, Stewart PS, Greenberg EP (1999). Bacterial biofilms: a common cause of persistent infections. Science 284:1318-1322.

38. Costerton JW, Montanaro L, Arciola CR (2005). Biofilm in implant infections: its production and regulation. Int J Artif Organs 28:1062-1068.

39. Chen ST, Wilson TG, Hammerle CHF. Immediate or early placement of implants following tooth extraction: review of biologic basis, clinical procedures and outcomes. Int J Oral Maxillofac Implants 2004; 19(5uppl): 1225 . 
40. Niyas M, Nazar N. ATRAUMATIC EXTRACTIONS: A REVOLUTION IN EXODONTIA-A REVIEW. International Journal of Clinical Dentistry. 2019 Jul 1;12(3).

41. Buser D, Dula K, Belser U, Hjorting-Hensen E. Localized ridge augmentation using guided bone regeneration. I. Surgical procedure in the maxilla. Int J Periodontics Restorative Dent 1993; 13 :29-45.

42. Lee J, Lee JB, Koo KT, Seol YJ, Lee YM. Flap Management in Alveolar Ridge Preservation: A Systematic Review and Meta-Analysis. International Journal of Oral \& Maxillofacial Implants. 2018 May 1;33(3).

43. Carmagnola D, Berglundh T, Lindhe J. The effect of a fibrin glue on the integration of Bio-Oss with bone tissue. An experimental study in labrador dogs. J Clin Periodontol 2002;29:377-383.

44. Misch CE, Dietsh-Misch F. A modified socket seal surgery with composite graft approach. J Oral Implantol 1999;25:244-250.

45. Landsberg CJ, Bichacho NA. A modified surgicalprosthetic approach for optimal single implant supported crown. Part 1. The socket seal surgery. Pract Periodontics Aesthet Dent 1994;6:11- 17.

46. Hegedus Z. The rebuilding of the alveolar process by bone transplantation. Dent Cosmos 1923; 65:736.

47. Drakos $D$, Engler-Hamm $D$. Ridge preservation: why and when. Implants. 2006;3:20-23.

48. Sonick M, Hwang D. Tooth extraction-an opportunity for site preservation. Contemp Esthetics. 2007 Feb; 11(2):36-41.

49. Tomlin EM, Nelson SJ, Rossmann JA. Suppl 1: Ridge Preservation for Implant Therapy: a Review of the Literature. The Open Dentistry Journal. 2014;8:66.

50. Allegrini S, Koening B, Allegrini MRF, et al. Alveolar ridge sock- ets preservation with bone grafting--review. Ann Acad Med Stetin 2008; 54(1): 70-81.

51. Carranaza FA, Newman MG. Reconstructive Osseous Surgery. In: Clinical Periodontology. Philadelphia, USA: WB Saunders Company; 1999;8:622-39.

52. Hyatt GW, Butler MC. The procurement, storage, and clinical use of bone homografts. Instr Course Lect 1957;14:343-73.

53. Klijn, R.J.; Meijer, G.J.; Bronkhorst, E.M.; Jansen, J.A. A meta-analysis of histomorphometric results and graft healing time of various biomaterials compared to autologous bone used as sinus floor augmentation material in humans. Tissue Eng. Part B Rev. 2010, 16, 493-507.

54. Dohan Ehrenfest, D.M.; del Corso, M.; Diss, A.; Mouhyi, J.; Charrier, J.B. Three-dimensional architecture and cell composition of a Choukroun's platelet-rich fibrin clot and membrane. J. Periodontol. 2010, 81, 546-555.

55. Vos, M.D.; Raghoebar, G.M.; van der Wal, J.E.; Kalk, W.W.; Vissink, A. Autogenous femoral head as grafting material for mandibular augmentation. Int. J. Oral Maxillofac. Surg. 2009, 38, 1320-1323.

56. AlGhamdi, A.S.; Shibly, O.; Ciancio, S.G. Osseous grafting part I: Autografts and allografts for periodontal regeneration-A literature review. J. Int. Acad. Periodontol. 2010, 12, 34-38.

57. Hammerle, C.H.; Araujo, M.G.; Simion, M. Evidence-based knowledge on the biology and treatment of extraction sockets. Clin. Oral Implants Res. 2012, 23, 80-82.

58. Rivault AF, Toto PD, Levy S, Gargiulo AW. Autogenous bone grafts: Osseous coagulum and osseous retrograd procedures in primates. J Periodontol 1971;42:787-96.

59. Pandit N, Pandit IK. Autogenous bone grafts in periodontal practice: a literature review. Journal of the International Clinical Dental Research Organization. 2016 Jan 1;8(1):27.

60. Zayner DJ, Yukna RA. Particle size of periodontal bone grafting materials. J Periodontol 1984;55:406-9.

61. Kumar J, Jain V, Kishore S, Pal H. Journey of bone graft materials in periodontal therapy: A chronological review. Journal of Dental and Allied Sciences. 2016 Jan 1;5(1):30.

62. Yukna, R.A.; Vastardis, S. Comparative evaluation of decalcified and non-decalcified freeze-dried bone allografts in rhesus monkeys. I. Histologic findings. J. Periodontol. 2005, 76, 57-65.

63. Aspenberg P, Kalebo P, Albrektsson T. Rapid bone healing delayed by bone matrix implantation. Int J Oral Maxillofac Implants 1988;3:123-127.

64. Becker W, Becker BE, Caffesse R. A comparison of demineralized freeze-dried bone and autologous bone to induce bone formation in human extraction sockets. J Periodontol 1994;65:1128-1133.

65. Froum S, Cho S-C, Rosenberg E, Rohrer M, Tarnow D. Histo- logical comparison of healing extraction sockets implanted with bioactive glass or demineralised freeze-dried bone allograft: a pilot study. J Periodontol 2002;73:94-102.

66. Dahlin, C.; Johansson, A. Iliac crest autogenous bone graft vs. alloplastic graft and guided bone regeneration in the reconstruction of atrophic maxillae: A 5-year retrospective study on cost-effectiveness and clinical outcome. Clin. Implant Dent. Relat. Res. 2011, 13, 305-310.

67. AlGhamdi, A.S.; Shibly, O.; Ciancio, S.G. Osseous grafting part II: Xenografts and alloplasts for periodontal regeneration-A literature review. J. Int. Acad. Periodontol. 2010, 12, 39-44. 
68. Rodella, L.F.; Favero, G.; Labanca, M. Biomaterials in maxillofacial surgery: Membranes and grafts. Int. J. Biomed. Sci. 2011, 7, 81-88.

69. Darby, I. Periodontal materials. Aust. Dent. J. 2011, 56, 107-118.

70. Artzi Z, Tal H, Dayan D. Porous bovine bone mineral in healing of human extraction sockets. Part 1: Histomorphometric evalu- ations at 9 months. J Periodontol 2000;71:1015-1023.

71. Nevins M, Camelo M, De Paoli S. A study of the fate of the buccal wall of extraction sockets of teeth with prominent roots. Int J Periodontics Restorative Dent. 2006;26: 19-29.

72. Jamjoom A, Cohen RE. Grafts for ridge preservation. Journal of functional biomaterials. 2015 Sep;6(3):833-48.

73. Nemcovsky CE, Serfaty V. Alveolar ridge preservation following extraction of maxillary teeth. Report on 23 consecutive cases. J Periodontol 1996;67:390-395. 27.

74. Mangano C, Piattelli A, Perrotti V, Lezzi G. Dense hydroxyapatite inserted into postextraction sockets: A histologic and histomorphometric 20-year case report. J Periodontol 2008;79:929-933.

75. Guarnieri R, Pecora G, Fini M, et al. Medical grade calcium sulfate hemihydrate in healing of human extraction sockets: clinical and histological observations at 3 months. J Periodontol 2004;75:902-908.

76. Iasella JM, Greenwell H, Miller RL, et al. Ridge preservation with freeze-dried bone allograft and a collagen membrane com- pared to extraction alone for implant site development: A clinical and histologic study in humans. J Periodontol 2003;74:990-999.

77. Fowler EB, Breault LG, Rebitski G. Ridge preservation utilising an acellular dermal allograft and demineralised freeze-dried bone allograft: Part 1. A report of 2 cases. J Periodontol 2000; 71:1353-1359.

78. Serino G, Biancu S, Iezzi G, Piattelli A. Ridge preservation fol- lowing tooth extraction using a polylactide and polyglycolide sponge as space filler: a clinical and histological study in humans. Clin Oral Implants Res 2003;14:651-658.

79. Shahroom NS, Jain AR. Prevalence of (alveolar ridge defect) using Seibert's classification in fixed partial denture patient. Drug Invention Today. 2018 May 1;10(5).

80. Marei MK, Nouh SR, Saad MM, Ismail NS. Preserevation and regenerarion of alveolar bone by tissueengineered implants. Tissue Eng 2005; 11:751- 767. 